\title{
Effect of isolated cabg on mild-to-moderate ischemic mitral regurgitation and cardiac remodeling
}

\author{
M Slavov", P Panayotov, D Panayotova, Y Peychev, V Kornovski \\ From 23rd World Congress of the World Society of Cardio-Thoracic Surgeons \\ Split, Croatia. 12-15 September 2013
}

\section{Background}

There is no consensus regarding the need of surgical correction of mild-to-moderate ischemic mitral regurgitation (IMR) during surgical revascularization procedure. Left alone it could either improve or progress to a more severe degree and deteriorate patient's condition, remodeling processes and quality of life.

\section{Methods}

To evaluate the changes in structure and function of the left cardiac chambers and mitral valve apparatus after isolated surgical revascularization we perform follow-up on 69 patients subjected to CABG in the setting of mild-tomoderate IMR. Mean follow-up was 22 (6 to 52) months. Left atrial and ventricular dimensions and volumes were evaluated preoperatively and at the follow-up.

\section{Results}

At follow-up $56 \%$ of all survivors showed improvement in IMR grade, $32 \%$ presented with the unchanged valve function and in only $12 \%$ IMR grade was more severe than preoperative. Preoperative effective ejection fraction increased from $26 \pm 8 \%$ to $32 \pm 14 \%(\mathrm{p}=0.002)$ at the follow-up. Left ventricular end-systolic volume index (LVESVI) decreased from $35 \pm 16 \mathrm{ml} / \mathrm{m} 2$ to $30 \pm 14 \mathrm{ml} / \mathrm{m} 2$ ( $\mathrm{p}=0.001)$. Significant left ventricular reverse remodeling $(\geq 15 \%$ reduction of LVESVI) was observed in $45 \%$ of all survivors. In $21 \%$ of all survivors significant left atrial reverse remodeling was present although mean left atrial volume index did not change significantly.

\section{Conclusions}

Isolated surgical revascularization improves the valve function in ischemic mitral regurgitation. It also triggers significant left ventricular reverse remodeling in half of the patients. It remains unclear how the persisting or advancing remodeling process seen in the other half changes the prognosis of these individuals.

Published: 11 September 2013

doi:10.1186/1749-8090-8-S1-O214

Cite this article as: Slavov et al:: Effect of isolated cabg on mild-tomoderate ischemic mitral regurgitation and cardiac remodeling. Journal of Cardiothoracic Surgery 2013 8(Suppl 1):O214.

* Correspondence: milen_slavov@yahoo.com

Department of Cardiac Surgery, "St Marina" University Hospital, Varna,

Submit your next manuscript to BioMed Central and take full advantage of:

- Convenient online submission

- Thorough peer review

- No space constraints or color figure charges

- Immediate publication on acceptance

- Inclusion in PubMed, CAS, Scopus and Google Scholar

- Research which is freely available for redistribution
C Biomed Central

\section{Biomed Central}

